\title{
Educational Characteristics of Adult Students in Portuguese Technological Schools
}

\author{
Ana Maria Ramalho Correia, Dulce Magalhães de Sá, Ana Cristina Costa, and Anabela Sarmento \\ acorreia@isegi.unl.pt, dulce@isegi.unl.pt, ccosta@isegi.unl.pt, sarmento@iscap.ipp.pt
}

\begin{abstract}
Despite a massive expansion of education in Portugal, since the 1970's, educational attainment of the adult population in the country remains low. The numbers of working-age people in some form of continuing education are among the lowest, according to the OECD and EU-27 statistics. Technological Schools (TS), initially created in the 1990's, under the umbrella of the Ministry of Economy in partnership with industry and industrial associations, aimed to prepare qualified staff for industries and services in the country, particularly in the engineering sector, through the provision of post secondary non-university programmes of studies, the CET (Technological Specialization Courses). Successful CET students are awarded a DET (Diploma of Technological Specialization), which corresponds to Vocational Qualification level IV of the EU, according to the latest alteration (2005) of the Education Systems Act (introduced in 1986). In this, CET's are also clearly defined as one of the routes for access to Higher Education (HE), in Portugal. The PRILHE (Promoting Reflective and Independent Learning in Higher Education) multinational project, funded by the European Socrates Grundtvig Programme, aimed to identify the learning processes which enable adult students in higher education to become autonomous reflective learners and search best practices to support these learning processes. During this research, both quantitative and qualitative methods were used to determine how students organise their studies and develop their learning skills. The Portuguese partner in the project' consortium used a two case studies approach, one with students of Higher Education Institutions and other with students of TS. This paper only applies to students of TS, as these have a predominant bias towards engineering. Results show that student motivation and professional teaching support contribute equally to the development of an autonomous and reflective approach to learning in adult students; this is essential for success in a knowledge economy, where lifelong learning is the key to continuous employment.
\end{abstract}

Index Terms - European project PRILHE (Promoting Reflective Independent Learning in Higher Education), Lifelong learning, Learning process, Adult students, Technological Schools.

\section{INTRODUCTION}

Globalisation and the need to create Knowledge Societies are the driving forces behind Lifelong Learning [1]. Actually, as technological progress impacts more and more on production processes and as individual consumer demands get further from traditional (manufactured) to more intangible products (such as health, leisure, tourism, finance), skills and competences have become the key for both social and economic progress and individual well being [2]. European Union (EU) policy-makers have set the goal for the EU economy and put forward the vision for Europe in the 21 st century in a defining statement, " (to) become the most competitive and dynamic knowledge-based economy in the world, capable of sustainable economic growth with more and better jobs and greater social cohesion" [3].

This highlighted the link between education and employment, between skills and prosperity and identified the successful exploitation of information and communication technology (ICT) as the means to achieving economic growth and full employment [4].

The so-called Lisbon Strategy was based on the pressing need to find solutions to persistent unemployment (affecting young people in particular) and called for concrete action and greater coordination of policies at all levels, "for building knowledge infrastructure and economic reform and modernising social welfare and education systems" (op. cit).

It is in the context of improving the qualifications of the workforce in Portuguese industry that Escolas Tecnológicas (Technological Schools - TS) were created in 1989, as part of the First European Commission Structural Funds Framework Programme, for Portugal - PEDIP I. This paper describes a case study of students at Technological Schools, part of the PRILHE (Promoting Reflective and Independent Learning in Higher Education) project, funded by the European Socrates Grundtvig Programme (113869-CP-12004-1-UK-GRUNDTVIG-G1PP). The next section describes the place of TS in the Portuguese Education System and refers to them as one of the possible ways to access higher education (HE); the third section introduces the aims and objectives of the PRILHE project and its methodology; the fourth section presents and discusses results. The final section draws conclusions and summarizes some of the best practices identified, in regard to becoming an autonomous and reflective learner. 


\section{Session S4G}

\section{TEChNOLOGICAL SCHOOLS}

TS have emerged, in 1989, under the auspices of the Ministry of Industry and Energy and as a partnership between INETI (National Institute for Engineering, Technology and Innovation, a R\&D State Laboratory), industrial associations, some lead enterprises of different sectors (e.g., Information and Communication Technology, Metalwork, Food Technology, Textile), higher education institutions and technological centres. At present, there are eight TS, which provide training for candidates who have finished their 10th or 11th year of schooling; in this case candidates will obtain of a vocational qualification level III of the EU. However the main thrust for TS is the provision of "post-secondary non university" vocational training for candidates with 12 years of schooling and/ or level III of vocational qualification. They can apply for a CET - Curso de Especialização Tecnológica (Technological Specialization Courses), leading to a DET - Diploma de Especialização Tecnológica, which corresponds to Vocational Qualification, level IV of the EU.

The TS have introduced into the Education and Training system, in Portugal, level IV qualifications addressing the specific needs of our intermediary level workforce. Furthermore, the TS possess flexible organizational forms, which enable them to keep pace with the technological transformations of the economy. Another characteristic of CET's is that successful completion of courses, undertaken under the auspices of an agreement, or protocol, with at least one Higher Education Institutions (HEI), guarantees access to HE. These protocols, agreed between the provider of CET and HEI for defined programmes of study, establish the conditions for recognition of training for advanced entry, within those HE programmes, without the need to sit the National HE Access examination, according to the DecreeLaw $n^{\circ} 88 / 2006$, of 23rd May, (article n.3) which constitutes the CET regulatory framework.

This blurring of the educational boundaries is in line with the perspective of lifelong learning proclaimed by OECD Education Ministers and aims to open up avenues for students to "better situate themselves with employment prospects and adult life" [5].

\section{PRILHE PROJECT}

The PRILHE (Promoting Reflective Independent Learning in $H E$ ) project was developed by a consortium of European HE organizations, in seven countries - namely, the Centre for Lifelong Learning, United Kingdom (coordinator); ISEGI, Universidade Nova de Lisboa, Portugal; Centre for Extension Studies, University of Turku, Finland; Georg August Universität Göttingen, Germany; The University of Lower Silesia, Poland; CREA, University of Barcelona, Spain; Department of Education, University of Stockholm, Sweden. The aims of the Project were:

- to identify the learning processes which enabled adult students in HE to become independent and reflective learners (to include study skills, self management, reflective processes and timings, learning to learn, analysing learning and teaching styles, interaction with lecturers and peers, institutional support and structures);

- to determine how this process could be better supported, in terms of materials, systems, staff, lecturers, web support, peers, family, friends; and to examine the interface between learning from experience and academic learning - the overlaps and conjunctions - and how experience could help academic learning and future learning, including in the workplace.

The overall objective was to identify models of good practice in HEI to share across Europe, in order to improve policy and teaching practices in this field. The primary focus of this project was the adult student, defined as a person over 25 (in Portugal, over 23) years old with at least one of the following characteristics [6]: left school with few or no qualifications, has been out of the educational system for a long time, has no previous higher education experience, and comes from a disadvantaged group.

During the research process, we became aware of the importance for students to be "Critical Autonomous Reflective Learners" (CARL) [7], that is, "critical in (their) awareness of the wider social conditions of learning; autonomous in (their) understanding of the inter-relationship between learner dependency and the potential for individual and group learning and action; reflective in the way (they look), from a certain distance, both at the learning process and the assumptions that underpin it". CARL thus links individual and social learning, seeing it as a transformative process which has the potential to change both individuals and social structures (op. cit:3).

To further reinforce the relevance of the PRILHE project, it should be noted that the European Council, at its meeting in March 2005, reviewed and re-launched the Lisbon Strategy, which among other policies, called for an increased investment in education and skills to equip the European citizens at all levels with the right knowledge, skills and attitudes (European Commission, 2005?). One of the "Central Policy Areas" was - to improve the adaptability of workers and enterprises and the flexibility of labour markets [8]. It is recognised that in an environment of rapidly changing economies and greater competition whether domestic or international - every worker should be aware of the need for greater self-critical understanding and adaptability, to anticipate and take stock of the inevitable reskilling required, when seeking employment in new sectors and different workplaces. It is in this context that the relevance of the PRILHE project can be appreciated.

The Portuguese partner used a two case studies approach - one studying students of HEI and the other students of TS. This was judged to be a valid way forward, taking into account the position of "post-secondary nonuniversity education" in the Portuguese Education and Training systems, as referred to above and reinforced by Whitman's comments [5]. 


\section{Session S4G}

In this paper, we discuss only the TS students' case study, as these have a strong focus in engineering disciplines. We used a quantitative and qualitative approach to gather information. A Web-based system was developed to collect the questionnaire data [9]. It was not possible to obtain information on the number of students attending the Technological Schools, thus the sampling rate could not be assessed. In order to increase the rate of questionnaire return, the Portuguese team made oral presentations of the PRILHE project in Technological Schools and, afterwards, the students were asked to fill the online questionnaire. Moreover, emails describing the project and stressing the importance of data collection were sent to most of the students, who were also encouraged to answer the questionnaire by lecturers and other people from their institutions. The Web-based system facilitated the compilation and analysis of data, and a sample of 71 validated questionnaires was obtained. The sample comprises the questionnaires of the students that attended the 2004/05 academic year.

The first set of questions aimed to collect students' personal information such as socio-demographic characteristics. The second set of questions focused on the eight categories established in the study design which impact on and are important in the learning process, aiding or hindering the efforts of the student to become more autonomous and reflective. The categories were:

1. Role of work/life experience in the learning process

2. Individual organization of learning - On the one hand, it might be said that learning is an individual issue; on the other, one might have a clear idea of how learning should be undertaken. Here, we are interested in the point of view of the student.

3. Reflection of contents - The statements reflect the importance of sharing of opinions and comments from lecturers regarding their performance and participation in critical debates.

4. Framing of the learning process - The statements deal with contexts of learning. To what extent is learning influenced by prior life experience or by specific learning situations?

5. Dialogue in the learning process - The statements deal with the relevance of communication with other people during learning.

6. Learning motivation - Here, we ask which motives and expectations caused the student to take up his / her studies and how they influence the learning process.

7. Learning approach - Everybody develops individual approaches to learning in the course of his/her learning life. Here, we are interested in the personal way of learning as well as the aims pursued with it.

8. Instructions and space for individual organization - For some people it is helpful to get clear instructions on how to organize their learning process, while others need space to proceed individually. In this case, we are interested in the learning conditions the student prefers.
For each category, we prepared a number of statements and asked the respondent student to classify each according to a 7 point Likert scale, ranging from "totally agree" to "totally disagree". Failure to answer was also noted. At a later stage, a qualitative approach, where we interviewed a selection of students in depth, was also developed. However, in this paper we only address the results obtained with the questionnaire; these are presented and discussed in the next section.

\section{RESULTS AND DISCUSSION}

By characterising the students' learning processes, we sought to verify how their life experiences could be used to assist academic learning and enable adult students to become more autonomous and reflective learners. Moreover, we also expected to be able to develop guidelines/recommendations, thereby increasing the chances of success for adult students.

\section{Characterization of the Technological Schools' student}

The majority of the Technological Schools (TS)' respondents were male $(77 \%)$ and the most frequent age group was from 25 to 34 years of age (73\%). Adult students represent approximately $75 \%$ of the sample. Most of the students (79\%) live with their family (wife/husband, children, brothers/sisters, parents, etc.), and $23 \%$ have children of their own. Only $15 \%$ of the students live alone, and a few (6\%) live with friends or fellow students. The percentage of adult students living with their families is $75 \%$, while $19 \%$ of them live alone. Approximately $30 \%$ of the adult students have children of their own.

Approximately $76 \%$ of the students have been out of the educational system for less than 5 years, $19 \%$ of them discontinued their studies for 5 to 10 years, and almost $5 \%$ did not engage in the educational system for more than 10 years. However, approximately $43 \%$ of them have participated in some kind of short course since their studies were discontinued, compared with $28 \%$ of the students under 25 years of age. Approximately $85 \%$ of the adult students are employed or have an occupation, compared with $79 \%$ of the students under 25 years of age. Summarising, the majority of students in TS in this sample are male, between 25 and 34 years old, living with their families and have been out of the educational system for less than 5 years.

\section{Role of work/life experience in the learning process}

By work experience we mean specialized knowledge (related to the trade or profession) and competences (e.g. talent for organization, ability to be critical, team spirit). We wanted to know the part played by work experience in the learning process. The great majority of students are of the opinion that their previous work/life experience supports ( $75 \%$ of students) and affects ( $80 \%$ of students; $85 \%$ of adults) their learning. This is also the opinion of approximately $80 \%$ of the students that have been out of the educational system for at least two years. Moreover, most of the students also recognize that lecturers value their work/life experience ( $75 \%$ of adults; $79 \%$ of students out of

October $22-25,2008$, Saratoga Springs, NY

978-1-4244-1970-8/08/\$25.00 C2008 IEEE $38^{\text {th }}$ ASEE/IEEE Frontiers in Education Conference S4G-16 


\section{Session S4G}

the educational system for at least two years). The work/life experience of their fellow students is also important for most of them, since $80 \%$ state that they learn from shared experiences.

As one can see, these students believe that their previous experience supports and affects their learning and that lecturers value it. They also recognize the importance of peers' experience. This idea confirms what Lave and Wenger state, "learning is a social process rather than a primarily and individual activity... Cooperative learning processes where ideas, insights, experiences can be exchanged and critically discussed, where the participants are exposed to alternative viewpoints on a given issue, that is to say where they learn with each other from each other and where they provide mutual help and solidarity, offer the opportunity for reflective and autonomous processes" [7] [10].

\section{Individual organization of learning}

Almost all (approx. 95\%) of the students have clear ideas about how they learn, and state that they have changed their approach to learning since they came back to education again (approx. 86\%). Most of the students (82\%) also agree that the way they learn is taken into account by lecturers. However, the percentage of students who feel insecure about the way lecturers expect them to learn is quite high (28\%) and opinions on this matter are quite diverse

These comments make one think that in order to overcome this problem lecturers should state clearly what the objectives of the unit/lesson are and what they expect students to learn/know.

\section{$I V$. Reflection of contents and framing of the learning process}

In general, students believe that lecturers expect them to reproduce what they are taught $(89 \%)$. Nevertheless, most of the students $(98 \%)$ state that the exchange of different views plays an important role in the learning process. In fact, respondents like to engage in critical discussions, both in informal situations $(81 \%)$ as well as in seminars and other situations where the debate is promoted (85\%). Moreover, the great majority of students consider that lecturers encourage critical thinking (98\%).

A student's background (personal, social, work, etc.) plays an important role in the learning process $(96 \%)$, but learning is also affected by situational aspects (97\%). However, there is no consensus in adult students' opinions on the way their feelings are connected with their learning, since $47 \%$ of them "agree" that they can not separate their feelings from their learning and 53\% "disagree"

Maybe this means that these students need to enjoy what they are doing/learning. The effort that they put everyday going to classes must have a meaning. It cannot be only for the sake of learning or having a career but also for their pleasure

However, when we focus on the opinions of the students that have been out of the educational system for at least 2

\section{8-1-4244-1970-8/08/\$25.00 @2008 IEEE} $38^{\text {th }}$ ASEE/IEEE Frontiers in Education Conference years, we verify that only $38 \%$ believe that they cannot separate their feelings from their learning. Maybe this means that the aspect of pleasure is not so important for those that have been out of the system for at least 2 years. Maybe, for them, the reasons to enrol in a course are more related to ambition, career or economic aspects. This issue needs further research.

\section{$V$. Dialogue in the learning process}

Although with different degrees of agreement, most adult students $(75 \%)$ state that they learn best on their own. Those results are hard to explain, because the great majority of adult students' state that they prefer to work in groups $(90 \%)$, and that they learn best by interacting with others $(92 \%)$. Moreover, $92 \%$ of the adult students affirm that their peers are helpful in the learning process.

\section{Learning motivation and approach}

Although one third of the adult students state that sometimes they don't know why they are taking the study in which they enrolled, most of them (96\%) agree that the reason why they are studying is because they want to progress in their careers. This percentage increases to $100 \%$ when we consider the students that are out of the educational system for at least 2 years; this reinforces the weight that these students give to career progression.

Moreover, $94 \%$ of the adult students agree that they also learn for the sake of the learning itself. Everybody develops individual approaches to learning in the course of his/her learning life. Therefore, the students' opinions on the personal way of learning, as well as the aims pursued with it, are quite diverse.

Most of the adult students are experimental learners (75\%), and are rather cautious when beginning something new (83\%). However, many of them feel that learning is not so easy $(30 \%)$. By experimental learners we mean those students that "organize their study strictly economically, are very keen on transparent study planning, take account of financial investment and learning effects and seem, in general, better organised" [11]. Usually these students are studying the so-called "hard disciplines" such as engineering, natural science, law, and economics. The other type of learner is the "discursive" one and prefers "discussions with others concerning the content of study, critical reflection on seminar programmes and serious thinking on the meaning of it all for their own lives" (op. cit: 42). These students usually are studying "soft sciences" e.g social sciences.

\section{Instructions and space for individual organization}

Results show that although many students need support to learn $(78 \%)$, most students also prefer to organize their learning process on their own (89\%). In fact, over $60 \%$ of adult students that "totally agree" with the statement 'I learn best when I organize my learning process on my own', also "totally agree", "agree" or "partially agree" with the statement 'In my learning I definitely need support'. This

October 22 - 25, 2008, Saratoga Springs, NY S4G-17 


\section{Session S4G}

maybe means that they like (or need) clear instructions about what to do and what they are expected to do but they also need some "territory" to try to experience something on their own. Maybe they want the lecturer to be a mentor or coach which gives them the possibility to make mistakes and "grow" through learning by doing.

Although we recognize that this dichotomy deserves further research, we believe that these answers reflect the way these students learn. Sometimes they want to feel independent, responsible and organize their learning on their own. But they also need to feel that they have support, if required and that there is someone they can go to for help.

Most adult students (77\%) state that without clear instructions learning is quite difficult for them; and $60 \%$ of the adult students feel that strict and rigid instructions disturb their learning processes.

\section{CONCLUSION AND GUIDELINES FOR BEST PRACTICES}

Within the auspices of the PRILHE project, we analysed a Portuguese case concerning students in Technological Schools (TS) (both conventional and adult students) and attempted to identify best practices for how to help these students to become more autonomous and reflective learners, since these competences are most important to perform successfully in a knowledge-based society.

The majority of adult students in TS, in the sample used for this exploratory study, are male, between 25 and 34 years of age, living with their family and have been out of the educational system for less than 5 years. They believe that their previous experiences, in both work and life, support and affect their learning and that lecturers value it. It is interesting to see that in TS all the students try to build a bridge between what is happening outside school with what is happening inside the classroom. They also recognize the importance of peers' experiences, as they state that they can also learn from each other.

These students have a clear idea about how they learn. They know what the best strategies are for them. They appreciate lectures delivered in a way which takes into account the way they learn. However, they recognize that sometimes they are not sure about what lecturers expect them to learn. This might happen maybe because sometimes lecturers are not clear about the objectives of the unit / topic being taught.

These students also say that some lecturers expect them to reproduce only what they are taught. This could be a problem, if lecturers only give importance to the memory of the student. Nevertheless, students are also of the opinion that discussions and the exchange of different views have an important role in the learning process. In fact, students enjoy very much to engage in critical discussions in all kinds of situations (formal and informal, seminars, etc.). Students also consider that lecturers encourage critical thinking and that they appreciate it.

Generally speaking, students recognize that their background (personal, social, work, etc.) plays an important role in their learning, but is also affected by the situation in which they learn. This means that the environment and situations created in the classroom are very important in this process.

Another interesting issue is that students state that they learn best on their own. Nevertheless, they also mention that they prefer to work in groups and that they learn best by interacting with others. These results may be explained if we think that in order to learn something we must follow a process; the first step may be to be on our own, reading notes and only after this to be with others, engaging in discussions. One must also be aware that students do not all learn in the same way, at the same pace and that idiosyncratic characteristics must be taken into account when preparing the environment for learning. We have identified that the majority of our respondents are experimental learners - not surprisingly because they are studying Engineering disciplines - needing clear objectives and wanting to see the usefulness of what they are studying in their professional lives. In this study we also identified learners who prefer interaction and discussions with peers. Some students need to get clear instructions on how to organize their learning processes, while others prefer having the space to proceed on their own.

In our sample, the majority of our respondents left school and decided later to return to learn. Although some of them state that sometimes they don't know why they returned to school and why they chose the programme of studies they enrolled in, most of them knew exactly the reasons why they returned. Usually, these are related to progress in their careers. Of course, we also identified some learners that had returned only for the sake of the learning itself. Although not inferred from the questionnaire and data presented above, this contact with TS allowed us to identify some best practices, not only in Portugal but in the other partners of the consortium. Some of these, which are described at the Handbook [7] and the Toolkit [12] produced from the PRILHE project [13] are:

- Induction sessions to help introduce students to the practices, services, administration processes, facilities and culture of an educational institution;

- Mentoring sessions where the students are helped / guided and supported by a mentor to develop their academic skills, knowledge and self-confidence as a learner;

- Personal Development Planning to encourage students to think through their work, reflect upon it, rework and review certain aspects of it and plan accordingly;

- Groupwork, where students can develop group processes - interaction, structure, leadership, etc.

We are aware that this sample might not represent the complete population of TS. So, for future work, we recommend spreading the scope of this study and seeing if this picture is also typical of other TS, in Portugal. Furthermore, this study should be expanded by further interviews, in order to examine in more depth the conclusions presented and identify any other best practices

October $22-25,2008$, Saratoga Springs, NY $38^{\text {th }}$ ASEE/IEEE Frontiers in Education Conference S4G-18 
at post secondary non-university, level IV (EU) of engineering education.

\section{REFERENCES}

[1] Prokou, E., "A Comparative Approach to Lifelong Learning Policies in Europe: the cases of the UK, Sweden and Greece", European Journal of Education, Vol. 43, No. 1, 2008, pp. 123140.

[2] Werquin, P., "Moving Mountains: will qualifications systems promote lifelong learning?", European Journal of Education, vol. 42 , no. 4, 2007, pp. 459-484.

[3] Lisbon European Council (23 and 24 March 2000). Presidency Conclusions. Council of the European Union. Viewed March 2008, http://ue.eu.int/ueDocs/cms Data/docs/pressData/en/ec/00100-r1.en0.htm

[4] Zantout, H., \& Dabir-Alai, P., "The knowledge economy in the context of European Union policy on higher education", Education, Knowledge and Economy, vol. 1, no. 2, 2007, pp. $125-143$.

[5] Whitman, I., "Tertiary Education Policy in OECD Countries: developing the human resource", European Journal of Education, Vol. 38, No. 2, 2003, pp. 191-198.

[6] Bourgeois, E., Duke, C., Guyot, J. L., \& Merrill, B. The adult university. Buckingham, England: Society for Research into Higher Education \& Open University Press, 1999.

[7] Johnston, R. \& Merril, B., Becoming a More Critical, Autonomous, Reflective Learner - Lecturer's Toolkit. Coventry: University of Warwick, 2007. Viewed March 2008. http://www.isegi.unl.pt/docentes/acorreia/documentos/Lecturer Toolkit_PRILHE_VF.pdf

[8] Commission of the European Communities. Lisbon Action Plan incorporating EU Lisbon Programme and Recommendations for Actions to Member States for inclusion in their National Lisbon Programmes. Brussels: CEC. SEC (2005) 192 [Companion document to the Communication to the Spring European Council 2005[COM (2005) 24) Working together for growth and jobs]. http://ec.europa.eu/growthandjobs/pdf/SEC2005_192_en.pdf
[9] Correia, A e Mesquita (Sarmento), A. Novos Públicos no Ensino Superior - desafios da sociedade do conhecimento. Lisboa: Sílabo, 2006.

[10] Lave, J., \& Wenger, E. Situated learning: Legitimate peripheral participation. Cambridge, UK: Cambridge University Press, 1991.

[11] Johnston, R. and Merrill, B. (Eds.) Enriching Higher Education: Learning and Teaching with Non-Traditional Adult Students: a Handbook, 2004. Viewed March 2008.

http://www2.warwick.ac.uk/study/cll/research/lihe/

[12] Kolvista, Mari \& Jokinen, Leena. Becoming a More Critical, Autonomous, Reflective Learner - Student Handbook. Coventry: University of Warwick, 2007. Viewed March 2008. http://www.isegi.unl.pt/docentes/acorreia/documentos/Student Handbook_PRILHE_VF.pdf

[13] PRILHE project. Viewed March 2008. http://www.pcb.ub.es/crea/proyectos/prilhe/project.htm

\section{AUTHOR INFORMATION}

Ana Maria Ramalho Correia, Universidade Nova de Lisboa \& INETI - Instituto Nacional de Engenharia, Tecnologia e Inovação, I.P., Portugal, acorreia@isegi.unl.pt

Dulce Magalhães de Sá, Universidade Nova de Lisboa, Portugal, dulce@isegi.unl.pt

Ana Cristina Costa, Universidade Nova de Lisboa, Portugal,ccosta@isegi.unl.pt

Anabela Sarmento, Instituto Superior de Contabilidade e Administração do Porto \& Centro Algoritmi (KMOWL) (Universidade do Minho), Portugal, sarmento@iscap.ipp.pt 